\title{
Globalisation, information technology and the emergence of niche transnational cities: the growth of the call centre sector in Dublin
}

\author{
Proinnsias Breathnach \\ Department of Geography, National University of Ireland, Maynooth County, Kildare, Ireland
}

\begin{abstract}
The development of information and communications technologies (ICT) has facilitated the emergence of a complex global urban system in which many formerly lower-order cities have been carving out "niche" specialist functions serving urban fields of transnational dimension. This is illustrated in the case of Dublin, which in recent years has been transcending its traditional role as Ireland's national metropolis through the development of a range of functions servicing mainly European markets. One such function comprises pan-European telephone call centre operations. The development and characteristics of this newly-emerging sector are described. It is argued that the growth of the sector confirms Dublin's - and Ireland's - dependent position in the international division of labour, and that its long-term sustainability is open to question. (C) 2000 Elsevier Science Ltd. All rights reserved.
\end{abstract}

Keywords: Information and communications technologies (ICT); Niche transnational cities; Telephone call centres; Dublin

\section{Introduction: The uneven impact of globalisation}

The concept of globalisation has secured remarkable currency in the academic discourse of the late 20th century, despite ongoing questions regarding both its meaning and extent (Clark and Lund, 2000). The development of internationally integrated production and distribution systems, seen by many as the key feature of globalisation, has been a spatially uneven process. A key factor in this respect has been the differential ability of regions to engage in the informational economy, based on new information and communications technology (ICT), which is the main source of wealth creation and economic growth in the modern world (Castells, 1993). The result has been what Friedmann (1995) calls a process of 'techno-apartheid' which has divided the globe into 'fast' and 'slow' worlds (Knox, 1995), distinguished by the connectedness of individuals, groups and regions to the world of telematics. This echoes Ingersoll's (1993, quoted in Knox, 1995) suggestion that the key division of the workforce is now that between those who have the capacity to operate ICT (the 'cyberproletariat') and those who do not (the 'lumpentrash').

E-mail address: proinnsias.breathnach@may.ie (P. Breathnach).
Golding (1996) makes a similar distinction between the 'technoliterati' and the 'techno-poor'.

While Knox defines the fast and slow worlds spatially, equating the former with the 'triadic' core and the latter with the remaining global periphery, Hoogvelt (1997) argues that the divide is, in essence, social rather than spatial, with elements of both worlds to be found in all regions of the globe. Thus, within advanced economies, a process of social polarisation has been widely reported (Friedmann, 1986; Sassen, 1994) and has been intimately linked by Graham and Marvin (1996) to the development of ICT use. This is not to suggest that those who work in the fast world are homogeneously well-paid and affluent; rather, they represent a wide range of remuneration levels depending on such factors as economic sector, location, function, ethnic group and gender (Castells, 1996). What they do tend to have in common, however, is relative employment security due to the high demand level for their ICT skills.

That said, it is nonetheless clear that, globally, there are major geographical variations in the relative balance between fast and slow worlds, with the former mainly to be found in the traditional core regions of North America, western Europe and Japan and an additional small group of newly industrialising countries which have had the institutional capacity to invest massively in modern ICT and associated educational infrastructures 
(Freeman, 1994). The slow world - found predominantly in the less developed countries of the global periphery and accounting for the bulk of the world's population - is becoming increasingly marginalised and is moving, as Castells (1993, p. 37) puts it, "from a structural position of exploitation to a structural position of irrelevance".

\section{The transnational urban system}

A key element in the globalisation process has been the development of growing links between the world's cities (the nerve centres of the informational economy), in the form of increasing flows of information, services, finance and currency, commodities and people. Thus, urban systems which in the past were largely defined in national terms have become increasingly integrated at the global level. This has led to the emergence of a transnational urban system (Sassen, 1994), comprising cities of varying sizes, locations, and economic functions. This system is dominated by a small number of 'world' (Friedmann, 1986) or 'global' (Sassen, 1991, 1994) cities, characterised by major concentrations of transnational corporate headquarters, advanced financial and producer services, and communications infrastructures. These are the world's "key command and control centres" (Amin and Graham, 1997, p. 413) whose functional reach is truly worldwide in scope.

Outside this select group of world/global cities, the globalisation process is causing urban centres everywhere to expand the international orientation of their economic bases. As Gottmann (1989, p. 64, quoted in Simon, 1995, p. 146) puts it:

Every substantial city nowadays aspires to a world role, at least in some specialty. This makes them expand linkages abroad, participating in more networks. All these trends contribute, little by little, to building up and intensifying the global weave of urban networks.

Many cities, therefore, have been pursuing selective "strategies for economic promotion and city marketing to establish themselves a profitable market niche" in the global economy (Wegener, 1995, p. 150). Typically, these cities place a premium on the attraction of outside capital which, in Friedmann's (1986) terminology, uses these cities as 'basing points' for the articulation of production and markets with respect to specialised sectors or areas. Examples of such cities include Singapore, which acts as a regional headquarters for transnational firms operating in Southeast Asia (Dicken and Kirkpatrick, 1991); Miami, which plays a key role in articulating trade and investment flows between the USA and Latin America (Sassen, 1994); and Luxembourg, which has carved out a niche for itself as the largest 'offshore' financial services centre in Europe (The Irish Times, February 9, 1996).

Due to the limited functional base and/or spatial reach of such cities, they are probably best described as 'transnational' rather than global. While in some cases, their spatial zones of influence may be relatively clearly defined, the growing role of ICT in their operations is rendering traditional concepts of territorial urban hinterlands increasingly meaningless. It may be preferable, therefore, as Friedmann (1995) suggests, to use the term 'urban field' to denote the economic (or, indeed, cyber) space served by such cities.

The proliferation of niche transnational cities with specialised functions is giving rise to what Sassen (1994, p. 52) calls "overlapping geographies of articulation". As a consequence, attempts to arrange the transnational urban system into neat hierarchical tiers (see Cohen, 1981; Friedmann, 1986) are increasingly futile (Friedmann, 1995). As Knox (1995, p. 9) has put it: "the flexibility of corporations within global networks and the warpage of new telecommunications media [are] constantly revising the role of 'lower-order' world cities".

In this paper, we examine the profound impacts which the globalisation process has been exerting on Dublin, the capital city of the Republic of Ireland. Originally, the economic and administrative hub of a colonial economy, Dublin found its dominant economic role becoming increasingly compromised by the installation of a dispersed branch-plant economy in Ireland in the 1960s and 1970s. More recently, however, Dublin has become increasingly central to the organisational strategies of many American transnational firms operating in Europe. This has resulted in the emergence of a number of niche functions with a predominantly international orientation.

The paper focuses on one such function, the international telephone call centre sector. The development of this sector in Dublin is placed in the context of general locational trends among back-office activities. As one such activity, the call centre sector has particular characteristics which bestow on Dublin a certain position within the corporate international division of labour. The paper concludes by discussing some of the implications of this position for the sustainability of Dublin's role as a leading location for international call centre activities.

\section{Dublin and the Irish economy}

Historically, Dublin developed as a classic colonial primate city in relation to an economic system which particularly in the 19th century - was dominated by the export of both agricultural produce and labour to the 
industrial core countries of Great Britain and the USA (Breathnach, 1988). Thus, Dublin acted as the centre of administration, the main port for exports and imports, and the hub of the national transport system, and was an order of magnitude larger, in population terms, than all other urban centres (with the exception of Belfast which, due to specific historical circumstances, developed a substantial industrial base in the 19th century). When Ireland was partitioned in 1922 and independence was secured by what is now the Republic of Ireland, Dublin had a population of 500,000 out of a total population of three millions in the newly independent state.

In the 1930s, Dublin's dominant position was further enhanced by the introduction of a vigorous policy of import-substituting industrialisation supported by protectionism, as the substantial industrial growth which ensued was mainly concentrated in the metropolitan region. By 1960, Dublin, with a quarter of the national population, accounted for almost one-half of the total manufacturing employment. However, industrial stagnation set in during the 1950s, as the limits presented by the small size of the domestic market were quickly reached. This led the government to abandon protectionism and opt instead for an export-led industrial policy based on the attraction of foreign direct investment from overseas. This policy received a major boost following Ireland's accession to the European Economic Community (now the European Union) in 1973, which allowed Ireland to be used as a low-cost base for serving the European market. This was particularly attractive to American firms, especially given Ireland's status as an English-speaking country with strong cultural/historical links with the USA. Since then, American firms have accounted for over one-half of all inward investment into Ireland.

In structural terms, the new branch plants set up in Ireland developed few local linkages of any kind; spatially, they also tended to avoid Dublin and other large urban centres, preferring more dispersed locations with little industrial tradition but plentiful supplies of unskilled labour (Breathnach, 1982; Gillmor, 1982). This reflected the fact that most foreign branch plants were mainly involved in low-skill assembly and packaging activities in the electrical/electronics engineering and pharmaceuticals/healthcare sectors (Telesis Consultancy Group, 1982). Thus, as foreign investment came to dominate the national economy (accounting for over one-half of industrial production and $80 \%$ of industrial exports by the mid 1980s), Dublin's role as control centre of the Irish economy (outside the realm of social regulation) experienced substantial erosion, although its position as main service centre for an increasingly prosperous nation saw the population of the metropolitan region grow to some 1.2 millions in 1991 - one-third of the total.

\section{The emergence of Dublin as niche transnational city}

Since the beginning of the 1990s, major changes have been occurring in the Irish economy which have impacted greatly on Dublin's functional role in relation both to the domestic economy and the international division of labour. Consistently high rates of economic growth have led to Ireland being portrayed variously as "Europe's tiger economy", the "Celtic tiger" and the "emerald tiger". From a position where, in 1980, Ireland's per capita GDP stood at just over $60 \%$ of the EU average, by 1998 Ireland had surpassed that average (Commission of the European Communities, 1999).

A range of factors have contributed to Ireland's rapid economic growth in the 1990s; however, of crucial importance have been a new surge in the inward investment and, more importantly, profound changes in the nature of this investment (Breathnach, 1998). In the realm of manufacturing, there has been a very significant upgrading in the technological content of inward investment and, associated with this, a pronounced expansion in the average size of new projects. This is linked, to a considerable extent, to the growing availability (due principally to demographic expansion and major state investment in education) of relatively lowcost but high-quality technically qualified workers. A common feature of this latest investment phase is that most of it has been concentrated in the Dublin area, a function primarily of the need for large numbers of college graduates (contrasting sharply with the low-skill operations of the 1960s and 1970s), allied to the need for more sophisticated local services.

Apart from the emergence of new forms of manufacturing investment, a very significant development in the 1990s has been a shift to inward investment in service activities. There have been three main components to this. Firstly, the establishment of an International Financial Services Centre (IFSC) in Dublin in 1987 has generated a considerable influx of operations attracted mainly by the low tax rates available in the centre. Employment in IFSC-licensed firms stood at 6500 in 1998. Secondly, there has been rapid growth in overseas software operations (Coe, 1997), employment in which reached 9500 by the end of 1997 . The vast majority of these are also located in the Dublin region, where relevant skilled personnel are concentrated. The third main component of recent growth of inward investment in services in Ireland has been the telephone call centre sector which provides the focus of the remainder of the paper.

\section{The internationalisation of back-office activities}

The location of telephone call centres in Ireland may be regarded as part of a new phase in the international 
relocation of back-office activities, a process which in itself is a relatively recent phenomenon. Back-office activities refer to those which require little face-to-face contact with other personnel either within or without the firm. They typically include such activities as payroll, accounting, subscriptions, billing, credit card services, claim processing, word processing, remote sales and reservations, and technical support (e.g., for personal computer users). These activities in turn tend to be highly routine, automated and labour-intensive.

There has been a growing tendency towards the spatial separation of back and front office activities (i.e., the latter being those requiring a high level of face-toface contact). Technically, this has been facilitated by the development of ICT which allows both a high degree of automation of information processing and the integration of remotely located back-offices with either front offices or the outside world through high-speed and high-volume telecommunications networks. However, the main motivating factor behind the separation of back from front office activities has been the desire to achieve significant cost savings by moving what tend to be a firm's most labour-intensive and therefore spaceusing office activities out of high-cost central city locations, where most firms locate their head offices (Castells, 1989).

In the case of North American cities, much attention initially focused on the relocation of back-offices to suburban locations where substantial reservoirs of predominantly female skilled clerical workers, who are prepared to work for relatively low wages, can be found (Nelson, 1986; Gad, 1985; Huang, 1988). More recently, there has been growing interest in the relocation of back-office workers out of metropolitan regions altogether to more remote locations (Castells, 1989; Howland, 1993; Warf, 1989). Increasingly, such movements have involved overseas destinations, motivated primarily by the prospect of accessing labour supplies which are both cheaper and frequently of higher quality (in terms of training, reliability and motivation) than those available in the home country. The availability of generous investment incentives has also been an important factor in the offshoring of back-office activities (Graham and Marvin, 1996; Wilson, 1995).

Suitable overseas locations for the back-office operations of American firms are not as widely available as in the case of manufacturing branch plants, due to the need for good telecommunications infrastructures and supplies of relatively cheap English-speaking workers with the requisite skills (Castells, 1989). As a result, the amount of offshoring of back-offices from the USA has been limited: the total numbers involved have been put by Wilson (1995) at no more than 35,000 in the early 1990s. At the same time, Wilson suggests that these movements provide an important pointer to the future direction the global organisation of services production will take. Much of the movement which has taken place has been to Caribbean countries such as Jamaica and Barbados. Other destinations which have attracted a significant level of back-office offshoring from the USA include the Philippines, India, China and Ireland.

Workers in offshore back-offices are predominantly young, flexible and female, mainly as a consequence of socialisation and gender stereotyping processes which steer mostly women towards this type of work. The resulting gender segmentation in turn facilitates the utilisation of social control processes similar to those which apply to female-intensive manufacturing operations (Breathnach, 1993). Gender segmentation also means that, while back-office work involves higher skill levels than, for example, electronics assembly, remuneration is not correspondingly higher due to the continuing tendency to ascribe low pay levels to what is considered to be 'women's work' (Christopherson, 1995).

Apte and Mason (1995) have identified the following as being influential factors in the decision on whether to relocate back-offices overseas or not:

- wage costs;

- availability of a modern telecommunications infrastructure;

- cultural and language similarity;

- availability of skilled labour;

- stability of the political and social environment;

- attitude of the host government to foreign investment;

- foreign currency restrictions and volatility;

- time zone difference.

Of these factors, crucial importance is attributed to the first two (see also Richardson and Marshall, 1996) which, in the Irish case, account for $80 \%$ of the running costs of telephone call centres; the remainder are seen as being either supplementary or significant in deciding on specific offshore destinations. The last factor listed applies particularly to back-office activities which are connected on-line to central home-country computers outside home-country office hours.

\section{Back-office development in Ireland ${ }^{1}$}

Apte's and Mason's list of locational factors provides a ready explanation for Ireland's attractiveness as a destination for American back-office operations. As regards labour factors, Ireland provides high-quality

\footnotetext{
${ }^{1}$ Much of the information for the following section has been provided by the Industrial Development Agency and Forfás, the Policy Advisory and Coordination Board for Industrial Development in Ireland, which maintain extensive databases on overseas firms operating in Ireland. Additional information has been sourced from interviews by the author with a range of personnel working in Irish call centres.
} 
skilled workers from a well-developed educational system with wage costs which, as Apte and Mason themselves show in relation to both clerical and professional workers, were typically about a half of those prevailing in the USA in the late 1980s. Furthermore, following a major investment programme initiated in the 1980s, Ireland now has a very advanced telecommunications infrastructure which offers very competitive rates for high-volume international traffic. Linguistically and culturally, there is a high degree of commonality between Ireland and the USA.

The Republic of Ireland also has an extremely stable political system and social environment, while the attitude of the Irish government to foreign investment is extremely positive, with its aggressive marketing of the country as a location for inward investment; low corporation tax rate $(10 \%$ for manufacturing and international services), capital and training grants, advice and other support services, no local content requirements and unlimited profit repatriation. The Irish currency is also relatively stable and there are no restrictions on currency movements. Finally, the minimum 5 hour time zone difference between Ireland and the USA has also proved influential for certain data-processing operations which played the pioneering role in terms of the establishment of offshore back-office activities in Ireland in the 1980s.

\section{The development of the call centre sector}

In the 1990s, the emphasis in the attraction of backoffice activites to Ireland has shifted to call centres (i.e., centralised locations from which services such as sales, reservations, information provision, technical support and banking are provided to a dispersed customer base by means of telephone). There has been a general acceleration in the establishment of call centres in recent years, motivated partly by increased attention among firms to customer service and the drive to direct marketing and partly by the growing availability of low-cost and high-volume long distance telecommunications services (including freephone facilities) (Richardson, 1994). Large firms operating in multiple regional and national markets have been moving towards the centralisation of call centre operations in one location (or a small number of locations), partly due to the economies of scale which can be achieved as a result. Many firms are availing of the consequent opportunity to establish centralised call centres in greenfield locations in order to introduce new work practices, such as variable working hours and local pay bargaining, which may have been difficult in existing locations (Richardson, 1994).

While most call centres remain focused on serving individual national markets, there has nevertheless been a significant growth of call centres with a transnational scope of operations. In the case of the EU, call centre centralisation may be seen as one element of a general process of rationalisation of production, marketing and administration among large firms operating on a panEuropean basis in response to the thrust towards integration of EU markets (Goddard, 1995). In 1997 the establishment of international universal freephone numbers to replace the pre-existing system of different national freephone numbers has also contributed to this centralisation process.

Ireland moved at an early stage to promote itself as a pan-European call centre location, offering, in addition to the existing grants and tax incentives, the cheapest rates in Europe for international freephone calls as well as low-cost, high-calibre, flexible bilingual staff. When the Industrial Development Agency (IDA) - the state agency responsible for promoting inward investment introduced its call centre programme in 1992, it projected the creation of 3000 jobs in the sector by the year 2000. However, this target was achieved as early as 1996 and, by mid-1998, some 50 centres had been set up employing 6000 persons.

\subsection{Characteristics of call centre firms ${ }^{2}$}

American firms dominate the Irish call centre sector, accounting for $70 \%$ of centres and over $80 \%$ of employment. Among the major US firms which have established call centres in Ireland are IBM, Compaq, Dell, Citibank, Hertz and Oracle. Female employment also dominates the sector, accounting for $70 \%$ of all jobs. The proportion is higher for the lower-skilled reservations and sales subsectors, and lower for the customer support subsector, which requires technical qualifications and pays correspondingly higher salaries.

Apart from the clerical nature of the work involved and the superior telephone skills which women tend to possess (Richardson and Marshall, 1996), a major reason for the high proportion of female labour is the central importance of language skills in the call centre sector, as women are much more inclined to study languages in both school and college. For three-quarters of call centre companies, the availability of language skills was stated to be either the first or second most important reason for coming to Ireland. Over one-half $(55 \%)$ of call centre employees use a foreign language in their work; of these, $43 \%$ are foreign nationals: thus, $23 \%$ of all employees are foreigners. Irish nationals are mainly used for the main continental languages (French, German, Italian, Spanish) with foreigners largely used for minority European languages (e.g., Scandinavian,

\footnotetext{
${ }^{2}$ The following information is mainly based on a survey of call centre operations conducted by Forfás in 1996 and made available to the author.
} 
Dutch, Portuguese) and non-European languages (e.g., Korean, Japanese).

\subsection{Locational trends}

Some $90 \%$ of Irish call centre employment is located in the Dublin region. While good telecommunications facilities are available throughout Ireland, call centre firms have been reluctant to locate outside Dublin for fear of being unable to source sufficient numbers of linguists, especially locally resident foreigners with minority language skills. There are also concerns about the availability of suitable office space and support services outside Dublin.

Even in Dublin there are emerging problems in getting adequate supplies of workers who can combine linguistic competence with the other skills required (telephone and keyboard skills and technical expertise for technical support functions). This is partly related to the rapid growth of the sector which has exceeded the supply of suitable personnel. One consequence of this has been an increasing problem of high labour turnover, reaching as high as $37 \%$ per annum for telesales workers, $25 \%$ for customer services and $17 \%$ for technical support (which provides the best-paid work in the sector); (The Tele Business Salaries and Skills Survey, 1998).

In the lower-skilled call centre activities such as sales/ reservations, additional problems have risen because, while technically these activities only require a secondary standard of education, only third-level graduates tend to have the language fluency required. However, these find it hard to accept the routine and repetitive nature of the work they are required to do. Apart from this problem of overqualification, the intensive, strenuous and closely monitored nature of the work also contributes to high turnover - a factor which tends to be universal in this sector (Nelson, 1986; Richardson and Marshall, 1996).

The more technologically skilled call centre activities such as technical support, on the other hand, face the problem that Irish information technology graduates (being mainly males who tend not to pursue language courses during the course of their education) in most cases do not have foreign language competence at the level required by call centres. Call centre firms are responding to this problem by increasingly importing foreign nationals for this type of work: of the 700 workers at the Gateway personal computer sales and technical support call centre in Dublin, 35\% are foreign nationals.

\section{Dublin in the international division of labour}

As we have seen, Dublin has, in the 1990s, carved out several niche international functions for itself, one of which, call centre activities, has been the principal focus of this paper. According to a report in The Irish Times (August 20, 1997), Ireland accounts for 30\% of all international call centres located in western Europe. The great bulk of these are to be found in Dublin. The central role of ICT in call centre activities has facilitated their centralisation in Ireland, from where markets spread across Europe and even further afield can readily be served. As Sassen (1995, p. 56) has observed: "Information technologies, often thought of as neutralising geography, actually contribute to spatial concentration".

Call centre activities, therefore, have helped Ireland to escape the bounds of geographical peripherality, thereby contradicting Wegener's (1995) gloomy prognosis which visualised cities in the periphery as inevitable losers from growing inter-urban competition in Europe. This has been cleverly portrayed in an IDA advertisement which shows Ireland at the centre of a surrounding group of disembodied European countries (Fig. 1). These latter are no longer seen as being more or less distant from Ireland, but as constituting a set of different language and market territories, all equally accessible from Ireland.

However, Dublin's growing international reach and the growing technological sophistication of its economic base should not mask the fact that, structurally, it retains a dependent position within the international division of labour. Its rapid recent economic expansion has been largely based on the attraction of branch plant operations which remain poorly embedded in the local economy (Breathnach, 1998). And, while the rising skill levels associated with recent inward investment have facilitated substantial improvement in living standards generally, in the specific case of the call centre sector, much of the employment which has been created remains relatively poorly paid - a fact which is directly linked with the high proportion of women workers in the sector, despite their high skill levels.

Furthermore, the rapid growth of the call centre sector in the 1990s looks increasingly unsustainable as the end of the decade approaches. Growing labour shortages are driving up labour costs which, in conjunction with increasing housing and transportation problems, are beginning to attenuate Dublin's attractiveness as a call centre location: according to a 1999 survey of call centre locations in Great Britain and Ireland, reported by Allen (1999), Dublin had fallen to the 29th position of 46 locations surveyed, having been in the top 10 in 1996. The response of the IDA has been to devote additional resources to promoting non-Dublin locations for call centre projects. However, even if this is successful in the short run, in the longer term the future of call centre employment will be increasingly threatened by technological developments, such as speech recognition technology and especially the rapidly 


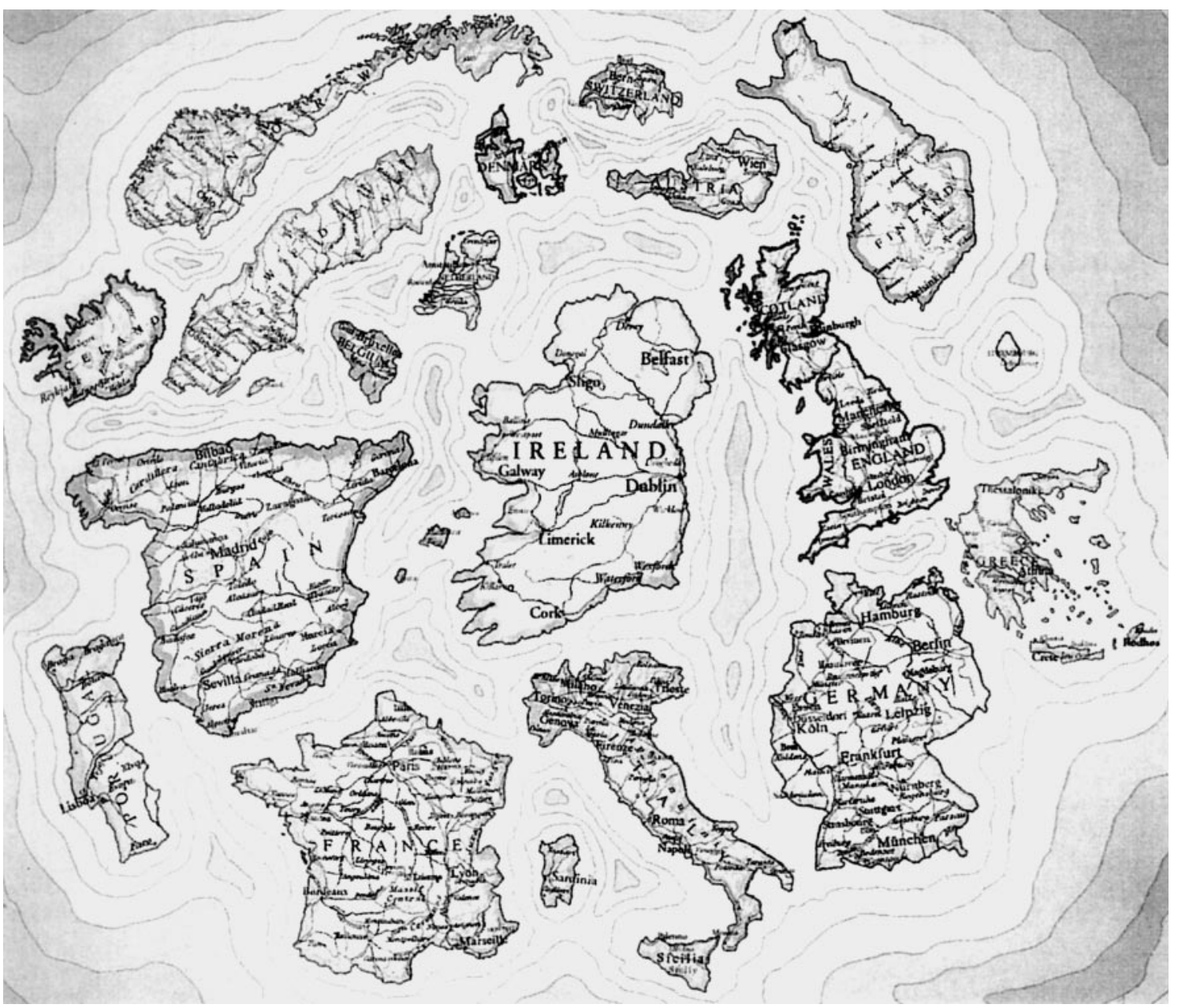

Fig. 1. "IRELAND. THE CALL CENTRE OF EUROPE” (Industrial Development Agency advertisement of Ireland as location for pan-European call centres).

growing use of the internet for making reservations, placing orders and seeking information.

The IDA has justified its promotion of the call centre sector, despite the inferior nature of much of the employment involved, largely on the grounds that it provides an initial base upon which more sophisticated forms of employment can be built. Its long-term strategy, in other words, is to encourage firms which have established call centres in Ireland to add on additional functions, such as financial management and software development, to these initial operations. Already there has been some success in this area of 'shared services' back-office activities: by mid-1997, some 25 such operations had been established, and were projected to employ over 3000 people by the year 2000 (information supplied by Forfás).

Ultimately, however, all of these activities remain as back-office activities, whose essential linkages are external to the Irish economy. In other words, their Irish location is not crucial to the parent companies of these operations; rather, it is contingent on the availability of certain attractions which may either be transient or reproducible elsewhere (Allen, 1999). As Wilson (1995) has noted, call centres are essentially a highly footloose sector, with few local economic linkages and little fixed investment in machinery and equipment: they therefore can be relocated quite readily in the light of changing comparative factor conditions.

\section{Conclusion}

In the past, Ireland has occupied a structurally dependent, peripheral, position within both the 'old' international division of labour between industrialised and primary-producing economies, and the 'new' international division of labour which emerged in the 1960s and 1970s, whereby routine, low-skill manufacturing activities were diffused to selected peripheral regions. More recently, Ireland has been one of the few peripheral regions which, through concerted investment in ICT infrastructure and associated education and training, has 
managed to adhere itself to the 'fast' component of the emerging global informational economy of the late 20th century. This has facilitated the attraction of considerable investment in ICT manufacturing and ICT-using services which has allowed Ireland - and particularly Dublin, where the bulk of this recent investment has been concentrated - to move towards the living standards of the world's core economies.

Nevertheless, due to its ongoing economic reliance on inward investment whose continuance is externally determined, Ireland remains a dependent economy, albeit located in what Todd (1995) has termed the "rich periphery" of the fast world, rather than the poor periphery of the slow world. In successfully targetting selected ICT-intensive investment in selected sectors, Dublin has managed to carve out a niche for itself as a transnational city. However, our examination of one of these sectors - call centres - has raised questions about the sustainability of this position, contingent as it is on exogenous economic, technological and political developments. Friedmann (1995) has pointed to the dynamism and volatility of the global urban system, with the relative positions of different cities waxing and waning over time. In this context, whether Dublin can maintain or even develop its role as a transnational city will depend on its adaptability to changing circumstances and, in particular, its ability to attract economic functions which are more central to the operations of the transnational firms which have become crucial to Ireland's continued economic well-being.

\section{References}

Allen, S., 1999. Call centre location: history versus mobility. Customer Contact Solutions 1, 24-25.

Amin, A., Graham, S., 1997. The ordinary city. Transactions, Institute of British Geographers 22, 411-429.

Apte, U.M., Mason, R.O., 1995. Global outsourcing of information processing activities. In: Harker, P.T. (Ed.), The Service Productivity and Quality Challenge. Kluwer Academic Publishers, Dordrecht, pp. 169-202.

Breathnach, P., 1982. The demise of growth centre policy: the case of the Republic of Ireland. In: Hudson, R., Lewis, J. (Eds.), Regional Planning in Europe. Pion, London, pp. 35-56.

Breathnach, P., 1988. Uneven development and capitalist peripheralisation: the case of Ireland. Antipode 20, 122-141.

Breathnach, P., 1993. Women's employment and peripheralisation: the case of Ireland's branch plant economy. Geoforum 24, 19-29.

Breathnach, P., 1998. Exploring the 'Celtic Tiger' phenomenon: causes and consequences of Ireland's economic miracle. European Urban and Regional Studies 5, 305-316.

Castells, M., 1989. The Informational City. Basil Blackwell, Oxford.

Castells, M., 1993. The informational economy and the new international division of labour. In: Carnoy, M., Castells, M., Cohen, S.S., Cardoso, F.H. (Eds.), The New Global Economy and the Information Age. The Pennsylvania State University Press, University Park, PA, pp. 15-43.

Castells, M., 1996. The Rise of the Network Society. Blackwell, Oxford.
Christopherson, S., 1995. Changing women's status in a global economy. In: Johnston, R.J., Taylor, P.J., Watts, M.J. (Eds.), Geographies of Global Change. Blackwell, Oxford, pp. 191-205.

Clark, E., Lund, A., 2000. Globalization of a commercial property market: the case of Coperhagen. Geogorum 31, 467-475.

Coe, N., 1997. US transnationals and the Irish software industry. European Urban and Regional Studies 4, 211-230.

Cohen, R.B., 1981. The new international division of labour, multinational corporations and urban hierarchy. In: Dear, M., Scott, A.J. (Eds.), Urbanization and Urban Planning in Capitalist Society. Mathuen, New York, pp. 287-315.

Commission of the European Communities, 1999. Travelling in Europe. Brussels.

Dicken, P., Kirkpatrick, C., 1991. Services-led development in ASEAN: transnational regional headquarters in Singapore. The Pacific Review 4, 174-184.

Freeman, C., 1994. The diffusion of information and communication technology in the world economy in the 1990s. In: Mansell, R. (Ed.), The Management of Information and Communication Technologies. ASLIB, London, pp. 8-41.

Friedmann, J., 1986. The world city hypothesis. Development and Change 17, 69-84.

Friedmann, J., 1995. Where we stand: a decade of world city research. In: Knox, P.L., Taylor, P.J. (Eds.), World Cities in a World System. Cambridge University Press, Cambridge, pp. 21-47.

Gad, G., 1985. Office location dynamics in Toronto: suburbanization and central district specialization. Urban Geography 6, 331351.

Gillmor, D., 1982. Manufacturing Industry in the Republic of Ireland. Bank of Ireland, Dublin.

Goddard, J.B., 1995. Information and communications technologies, corporate hierarchies and urban hierarchies in the new Europe. In: Brotchie, J., Batty, M., Blakely, E., Hall, P., Newton, P. (Eds.), Cities in Competition. Longman, Melbourne, pp. 125-138.

Golding, P., 1996. World wide wedge: division and contradiction in the global information infrastructure. Monthly Review 48, 70-85.

Gottmann, J., 1989. What are cities becoming the centres of? Sorting out the possibilities. In: Knight, R.V., Cappert, G. (Eds.), Cities in a Global Society. Sage, London.

Graham, S., Marvin, S., 1996. Telecommunications and the City: Electronic Spaces, Urban Places. Routledge, London.

Howland, M., 1993. Technological change and the spatial restructuring of data entry and processing services. Technological Forecasting and Social Change 43, 185-196.

Hoogvelt, A., 1997. Globalisation and the Postcolonial World. Macmillan, London.

Huang, S., 1988. Office suburbanisation in Toronto: fragmentation, workforce composition and laboursheds. Ph.D. Dissertation, University of Toronto.

Ingersoll, R., 1993. Computers "R" us. Design Book Review 27, 5.

Knox, P.L., 1995. World Cities in a World-System. In: Knox, P.L., Taylor, P.J. (Eds.), World Cities in a World System. Cambridge University Press, Cambridge, pp. 3-20.

Nelson, K., 1986. Labor demand, labor supply and the suburbanization of low-wage office work. In: Scott, A.J., Storper, M. (Eds.), Production, Work, Territory: The Geographical Anatomy of Industrial Capitalism. Allen \& Unwin, Winchester, MA, pp. 149 171.

Richardson, R., 1994. Back-officing front office functions - organisational and locational implications of new telemediated services. In: Mansell, R. (Ed.), The Management of Information and Communication Technologies. ASLIB, London, pp. 309-335.

Richardson, R., Marshall, J.N., 1996. The growth of telephone call centres in peripheral areas of Britain: evidence from Tyne and Wear. Area 28, 308-317.

Sassen, S., 1991. The Global City: New York, London, Tokyo. Princeton University Press, Princeton, NJ. 
Sassen, S., 1994. Cities in a World Economy. Pine Forge Press, Thousand Oaks, CA.

Sassen, S., 1995. Urban impacts of economic globalisation. In: Brotchie, J., Batty, M., Blakely, E., Hall, P., Newton, P. (Eds.), Cities in Competition. Longman, Melbourne, pp. 36-57.

Simon, D., 1995. The world city hypothesis: reflections from the periphery. In: Knox, P.L., Taylor, P.J. (Eds.), World Cities in a World System. Cambridge University Press, Cambridge, pp. 132155.

The Tele Business Salaries and Skills Survey, 1998. Computer Staff Recruitment, Dublin.

Telesis Consultancy Group, 1982. A Review of Industrial Policy. National Economic and Social Council Report No. 64, Dublin.
Todd, G., 1995. 'Going global' in the semi-periphery: world cities as political projects. The case of Toronto. In: Knox, P.L., Taylor, P.J. (Eds.), World Cities in a World-System. Cambridge University Press, Cambridge, pp. 192-212.

Warf, B., 1989. Telecoms and the globalization of financial services. Professional Geographer 41, 257-271.

Wegener, M., 1995. The changing urban hierarchy in Europe. In: Brotchie, J., Batty, M., Blakely, E., Hall, P., Newton, P. (Eds.), Cities in Competition. Longman, Melbourne, pp. 139-160.

Wilson, M.I., 1995. The office farther back: business services, productivity and the offshore back-office. In: Harker, P.T. (Ed.), The Service Productivity and Quality Challenge. Kluwer Academic Publishers, Dordrecht, pp. 203-224. 